\title{
Research on the Teaching Practice of Public English Course in Higher Vocational College under the Background of "Internet plus"
}

\author{
Liu Ying \\ Liaoning Urban Construction Technical College, Liaoning Shenyang, China, 110122
}

Keywords: Internet; higher vocational education; public English; teaching; practice

Abstract: As the level of globalization in the world continues to increase, economic exchanges and cooperation between China and other countries are also increasing. English has gradually become a language that all countries need to learn, and how to properly apply the "Internet" to improve the efficiency and effectiveness of public English teaching in higher vocational schools is a problem that many higher vocational colleges need to study in depth.

\section{Introduction}

With the continuous development of China's economy, China's education industry is also developing continuously. Higher vocational colleges have also begun to pay attention to the teaching of English courses, and have reformed them to improve students' comprehensive quality and professional level, and improve students' employment competitiveness. Public English belongs to the public courses of higher vocational colleges. How to stimulate students' enthusiasm for learning, improve teaching efficiency and effect is an issue that English teachers in higher vocational colleges need to consider.

\section{The deficiency of public English teaching in traditional higher vocational colleges}

\subsection{Teaching concept is not advanced enough}

In the past, in the public English teaching of higher vocational colleges, the teaching concept of English teachers was not advanced enough. It paid more attention to the test scores of students. In the process of teaching, the modern teaching methods were not applied reasonably, and the teaching methods were relatively simple, which would affect students' interest in learning. In order to ensure that they can pass the final exam, students who are not English majors may memorize the key points drawn by the teacher. They do not use the electronic dictionary and other tools reasonably, and have not scientifically formulated the study plan. This will directly affect the efficiency and quality of public English teaching in higher vocational schools. 


\subsection{Single teaching method}

Because the teaching concept of vocational English teachers is not advanced enough, it does not use a variety of teaching methods. A single teaching method will directly affect students' interest in learning. The infrastructure and equipment of higher vocational colleges are not advanced enough. It is also an important factor affecting the diversity of teaching methods. For example, some classroom multimedia devices cannot be connected to the Internet, and teachers can only use slides. To teach students, especially in the public English class, the teachers play slides on the podium, explain the students according to their own ideas, and do not pay attention to whether students understand these knowledge points. Because students have different English foundations, some students with poor foundations can't understand the teaching content of teachers. In the long run, they will attack the enthusiasm of these students, and then there will be disciplinary behaviors such as class sleep, which seriously affects the effect of public English teaching in higher vocational schools

\subsection{Poor learning atmosphere}

If the English teachers in higher vocational schools do not reasonably apply the Internet teaching resources, it will directly affect the classroom teaching atmosphere. A single and boring teaching method can not stimulate students' enthusiasm for learning. Therefore, students will not actively learn about public English in their spare time, which will directly affect students' English proficiency and affect their employment competitiveness. In addition, the traditional teaching method is based on teachers as the main body of teaching. Students only passively accept knowledge, and there is less communication between teachers and students, which seriously affects the learning atmosphere in classroom teaching.

\section{Measures to Improve the Teaching Effect of Public English Courses in Higher Vocational Colleges}

\subsection{Reforming teaching concepts}

\subsubsection{Pay attention to the practicality of English}

In today's world where cooperation and exchanges are increasing, English has become an essential knowledge for all talents. Therefore, its practicality and market value are high. Higher vocational colleges need to pay attention to the quality of public English teaching. In the process of public English classroom teaching in higher vocational colleges, it is necessary to pay attention to cultivating students' English application ability, improve their English quality, and cultivate application-oriented talents with high English quality for the society.

\subsubsection{Improve the relevance of English teaching}

The teaching mode of most higher vocational colleges in China is " $2+1$ " mode. The academic system of higher vocational colleges is three years, while the students study and study time is two years, and the internship and job search time is one year. Therefore, in the two-year study period, students need to master multi-disciplinary knowledge such as basic knowledge, professional knowledge, and English knowledge. This is a heavy task for students. Therefore, in the process of public English teaching in higher vocational colleges, it is necessary to pay attention to the explanation of important, basic and practical English knowledge, so as to improve the English level of students. For example, tourism majors need to have the ability to communicate with foreign 
tourists in English, and also need to use English to explain the attractions; trade students need to have a higher level of English knowledge, because the trade students need to view English documents, English orders. In a word, public English teaching in higher vocational colleges needs to be targeted in accordance with the future development direction of students.

\subsubsection{Reforming teaching concepts}

In recent years, the demand for talents in countries and industries around the world has changed. More talents with innovative consciousness and innovative ability are needed. Therefore, higher vocational colleges need to reform the teaching methods of public English and cultivate students' sense of innovation. Therefore, English teachers in higher vocational schools need to change their teaching concepts, attach importance to the status of students as learning subjects, respect students, and scientifically select teaching objectives and teaching content according to the development direction of students. In addition, vocational English teachers need to strengthen communication with students, take effective measures to stimulate students' enthusiasm for learning, improve students' English knowledge and English application ability, which is of great significance to the future development of students.

\subsection{Optimization of teaching textbooks}

Since most vocational colleges adopt the "2+1" teaching mode, students have less time to learn English knowledge, and some higher vocational colleges do not pay enough attention to the effect of public English teaching. Therefore, when setting up the curriculum structure in higher vocational colleges Professional courses take up most of the time and there are fewer English classes, which is also an important factor affecting students' English proficiency. The study found that most of the English textbooks in vocational colleges in China are textbooks to improve students' English knowledge and reading ability, and they do not pay much attention to cultivating students' English listening and English application skills. In the process of teaching, higher vocational English teachers pay more attention to English grammar, reading and other teaching content, and do not pay attention to cultivating students' English application ability. In addition, higher vocational colleges choose a unified teaching material to ensure that students in the college can pass the English proficiency test prescribed by the state. Because these textbooks are not selected for different majors, they are unable to meet the needs of students for English learning. In order to improve the effectiveness of public English teaching in higher vocational schools, it is necessary to pay attention to the choice of English textbooks.

\subsubsection{Pay attention to the pertinence and practicality of English textbooks}

Due to the short study time, higher vocational colleges have reduced the English class time in order to improve teaching efficiency. In order to improve the effectiveness of English teaching, higher vocational colleges need to select targeted and practical English textbooks according to the needs of English majors of different majors, so as to improve students' English knowledge and English application ability.

\subsubsection{Concise knowledge}

The English textbooks selected by some higher vocational colleges in China include English grammar, reading, English vocabulary and other content. These English knowledge will take up a lot of time for students, resulting in less practice time in English practice, and because these English knowledge is not professional and practical, the English knowledge is rarely used after the students 
are employed. Therefore, in order to improve students' English level and improve their professional quality, higher vocational colleges need to pay attention to the professionalism and practicality of English textbooks.

\subsubsection{Moderate difficulty}

The content of English textbooks is too simple and too difficult to affect students' English knowledge level and English application ability. Therefore, when selecting English textbooks, higher vocational colleges need to analyze factors such as students' knowledge level and English basic level. Reasonable choice of appropriate English textbooks and ensure that the English teaching is moderately difficult, this will ensure that students can master these English knowledge. The study found that boring, single teaching content and teaching methods cannot stimulate students' enthusiasm for learning. Thus, when selecting public English textbooks, higher vocational colleges need to choose vivid and interesting teaching materials, which can stimulate students' enthusiasm for learning and improve their English knowledge.

\subsection{Strengthen practical teaching}

In order to improve the English application ability of vocational college students, higher vocational colleges need to strengthen English practice teaching. At this stage, in the process of public English teaching in some higher vocational colleges in China, the emphasis on theoretical knowledge teaching is still emphasized, and English practice teaching is not strengthened, for that reason, students' English application ability is not high enough. Non-English majors need to have the necessary knowledge of English and use this knowledge of English to communicate with others. Therefore, higher vocational colleges need to strengthen English practice teaching.

\subsubsection{Setting up a vocational English teaching system for higher vocational education}

Higher vocational public English courses need to include both English theoretical knowledge and English practice training. Influenced by factors such as teaching time, teaching space, and syllabus, some higher vocational colleges in China pay more attention to students' understanding and mastery of English theoretical knowledge, and their English application ability is not high enough. Therefore, in order to improve students' English application ability, higher vocational colleges need to strengthen English practice teaching and training. The public English practice teaching system of higher vocational colleges is composed of self-learning resource library module, human-machine oral simulation training module, word mnemonic system module and training course module. Furthermore, you need to increase the English Corner, English contest and other activities. In the process of teaching, higher vocational English teachers also need to actively apply multimedia digital teaching technology, which can effectively solve the constraints of English learning time and learning space. Moreover, the use of multimedia teaching resources, teaching technology can stimulate students' enthusiasm for learning, which is of great significance to improve their English. The word mnemonic system module allows students to remember multiple words during the game; organizing English practice classes, English contests and other activities can enhance students' English application ability and enhance their employment competitiveness.

\subsubsection{Set up public English training courses}

Higher vocational public English training courses can help students master the basic knowledge of English and improve their practical ability in listening, speaking and writing by simulating real-life situations. This kind of teaching method can improve students' comprehensive ability while 
improving their English application ability, to stimulate students' enthusiasm for learning and enhance students' sense of innovation and innovation.

The English training course setting has the following characteristics: First, the task is driven. In the public English training course of higher vocational education, the whole teaching framework is set according to its teaching tasks. The main purpose is to enable students to master the practical ability of listening, speaking, reading and writing in English while completing the practical tasks, so as to improve students' English application ability and improve their professional quality and professional level; Second, Operability. Higher vocational colleges train professional talents for the society, and because of the heavier learning tasks of higher vocational students, public English teaching needs to pay attention to its practicality. For example, the Presentation module, its main role is to prepare a publicity plan, and its use The language is English. In order to use this module, students need to have certain knowledge of English; Third, practicality. Higher vocational English teachers need to change their own teaching concepts. In the process of public English practice teaching, they must adhere to the principle of "Learning by Doing" so that they can fully reflect the teaching objectives of practical courses; Finally, professionalism. In order to improve students' English application ability and improve their competitiveness, higher vocational English teachers need to integrate English knowledge and professional knowledge in the teaching process.

\subsection{Reforming teaching methods}

In the traditional teaching mode, teachers are in an active position, and students can only passively accept various knowledge, which will directly affect students' enthusiasm for learning, and thus affect the efficiency and effectiveness of public English teaching. At the same time, due to the poor enthusiasm of students, their knowledge of English is low, which is not good for the future development of students. Therefore, higher vocational colleges need to change their teaching methods and teaching methods to improve students' English application ability and improve their employment competitiveness.

\subsubsection{Reforming teaching methods}

Higher vocational English teachers can use the driving task teaching method in the teaching process. For example, in the public English teaching process of tourism majors, teachers can divide students into multiple study groups, and each group of students selects a tourist attraction. Collect relevant materials in the spare time, master the history of tourist attractions, customs, travel routes, etc., and prepare English travel speeches. Each group selects one person to present their speeches in class, and other groups of students and teachers evaluate their speeches. Throughout the teaching process, teachers are no longer the main body of teaching, and become the guide of teaching. This is of great significance to give full play to students' subjective initiative and stimulate students' interest in learning. In short, the use of this teaching method can effectively improve students' ability to apply English knowledge.

In addition to the above teaching methods, higher vocational English teachers can also use the creation of situational teaching methods. In the process of teaching, English teachers can create situations related to daily life or profession. In this situation, students can master relevant English knowledge by playing different roles. Before the role play, students need to make relevant preparations. First, they need to find relevant information through the Internet or the library, compile situational dialogues and conduct drills, then they need to perform the situation in the classroom. After the performance, the whole class of students and teachers will evaluate it to help them find the inadequacies and improve them. This is of great significance to improve students' English proficiency. 


\subsubsection{Optimize teaching methods}

In order to improve the efficiency and effectiveness of public English teaching, English teachers need to use information technology reform teaching methods in the teaching process. The use of advanced information technology for teaching can improve the English classroom teaching atmosphere, stimulate students' enthusiasm for learning, thereby improving teaching efficiency and teaching effect, which is of great significance to improve students' English application ability and improve their professional competitiveness. For example: in the English classroom teaching process, teachers can use multimedia equipment to play English movies, English songs, celebrity speeches and other content, which not only stimulates students' enthusiasm for learning, but also enhances students' listening level.

\subsection{Optimization evaluation method}

Most of the higher vocational colleges in China use the final exam method to assess the level of English knowledge of students. Most of the higher vocational colleges use the written test to conduct assessments. They do not pay attention to assessing students' listening level and oral level. English test papers are also unified papers. Different examination papers are not set for different professions, this kind of assessment method is not reasonable enough. Therefore, in order to improve the English application ability and professional ability of vocational students, it is necessary to reform the evaluation method, select the most appropriate assessment methods for students of different majors, and strengthen the assessment of students' listening ability and speaking ability.

\section{Conclusion}

To sum up, in order to improve the employment competitiveness of vocational students, it is necessary to pay attention to the efficiency and quality of public English teaching. Higher vocational colleges need to choose appropriate and targeted English textbooks for English teaching. At the same time, it is necessary to increase the English practice teaching class, so as to enhance the students' English application ability and lay a solid foundation for their future development.

\section{Acknowledgment}

\section{Liaoning Province Education Science “13 ${ }^{\text {th }}$ Five-year Plan”2018 Annual Project (JG18EB076)}

\section{References}

[1] Peng Haitao. Discussion on the Reform of the Mixed English Teaching Model of Higher Vocational Education Based on "Internet + "[J]. Journal of Qingdao Vocational and Technical College, 2016, 29(3):38-41.

[2] Zeng Yan. Practice and Research on the Public English Micro Teaching Mode in Higher Vocational Education [J]. Journal of Jinan Vocational College, 2016(6):37-39.

[3] Kong Kai, Xia Wenxian, Wang Jing. Research on the Introduction of Chinese Traditional Culture in the Teaching of Public English in Higher Vocational Education under the Background of "Internet + "[J]. Journal of Liaoning Institute of Science and Technology, 2016(3):73-75.

[4] Zhang Fang. A New Probe into the Grading Teaching Model of Higher Vocational Public English in the Background of MOOC [J]. Journal of Xiangyang Vocational and Technical College, 2016, 15(2):95-97.

[5] Liu Xiaojing. Research on the Application of Digital English Teaching in Higher Vocational Education in the Background of Classified Teaching [J]. Journal of Kaifeng Education College, 2016, 36(5):151-152.

[6] Tian Ye. Discussion on the Design of SPOC Course in Higher Vocational Public English under the Environment of "Internet +"[J]. Journal of Jiamusi Vocational College, 2017(5):13-14. 